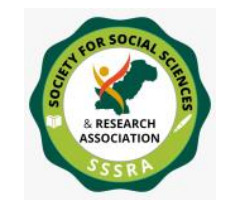

Pak. Journal of Int'L Affairs, Vol 4, Issue 2 (2021) Evaluation of Customer Relation Management ...

\title{
EVALUATION OF CUSTOMER RELATION MANAGEMENT: A CASE STUDY OF PUBLIC AND PRIVATE BANK OF PAKISTAN
}

\author{
Aneel Bhatia \\ Assistant Professor \\ Institute of Commerce \\ University of Sindh \\ Jamshoro - Pakistan \\ aneel1969@hotmail.com \\ Dr. Imdad Ali Khowaja \\ Assistant Professor \\ Department of Economics \\ University of Sindh \\ Jamshoro - Pakistan \\ imdadalikhowaja@gmail.com \\ Dr. Kamleshwer Lohana \\ Assistant Professor \\ Mehran University Institute of Science, Technology, and Development \\ Jamshoro - Pakistan \\ kamleshwer.lohana@faculty.muet.edu.pk
}

\begin{abstract}
:
Purpose of the Study: The study pertains to the knowledge, management and the creativity of the banking sector. It has been examined by the survey of primary data from the perspective of the customer's security and confidence of relationship building with public and private institutions. Therefore, the issue has been revisited to explore the variance between the application of customer relationship management in private and public banks.
\end{abstract}

Methodology: The number of the respondents, 249, including the depositors and borrowers, has been taken from the total universe of the population of selected list of the public and private banks branches of 


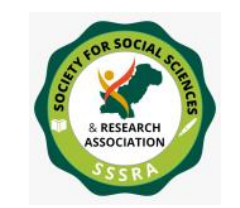

Pak. Journal of Int'L Affairs, Vol 4, Issue 2 (2021) Evaluation of Customer Relation Management ...

Hyderabad with a $95 \%$ reasonable level of confidence. To examine the data, a simple Independent T-Test was applied to find the variance between the variables.

Findings: The empirical result $p=<0.05$ indicates there is a variance between the carry out customer relationship management in the public and private banks. Private banks are more aggressively practicing their ideas in comparison to local banks.

Applications of this Study: The study will be useful for the students of commerce and business studies to understand the concept and evaluate practices of CRM in the service sector and for the management and staff related to the service sector for business development and career development.

Novelty and originality of the work: The study will contribute more in the dynamic expansion in the business activities, particularly in the service sector of Pakistan, to operate, maintain and startup a profitable business for a longer period which is mutually beneficial for management, staff and customers. While the service sector in Pakistan facing the issues in business decision making with respect to CRM practices such as to retain current and future profitable client providing quality services.

\section{Keywords: Knowledge; Management; Creativity; Customer; Service; Profitability}

\section{Introduction:}

The important function of the banks is to provide enough monetary resources so every individual can participate in the economic development and growth of the country. The public commercial banks played a significant role in economic development in Pakistan till to1990. In order to answer increasing demand for funds for the capital development in the country, local and foreign investors were permitted to establish banking operations in 1990. The new establishments (i.e., private and foreign banks) had changed the dynamics 


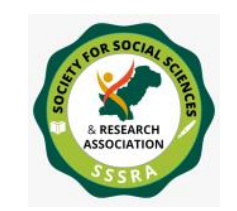

Pak. Journal of Int'L Affairs, Vol 4, Issue 2 (2021) Evaluation of Customer Relation Management ...

of performance and development of banking operations. The marketing reforms were adapted to enhance profitability and financial assets by entering the profitable customer in the business fold. In the middle of the twentieth century the private and foreign banks initiated to practice the concept of customer relationship management (CRM). The model of customer relationship management involves the information technology to arrange, mechanize, and accelerate the sales growth and earnings, quality customer service and to provide technical assistance, to create a long-term association with current and attract future customers. The productivity of business banks depends on information, the executives, and innovativeness. (Kumar \& Reinartz, 2012).

\subsection{Traditional Marketing and Modern Relationship Marketing}

Publicizing, putting boards, print, and electronic media to sell product, to convey the item data to the targeted client to buy are the major technique of traditional marketing. Its The fundamental goal is the sale. While the modern relationship marketing scheme begins after the sale to build a solid relationship with the client. (Brink \& Berndt, 2008).

\section{Literature Review:}

Meena \& Sahu (2021), the authors have classified and summarized the research work on the customer relationship management has been done during the last 21 years (i.e., 2000 to 2021) on the basic research question, data collection and analysis tools used in the primary and review papers in various parts of the world. According to the findings, the greater part $(95 \%)$ of the research work on CRM has been published in various research journals in the year 2009. The. The remaining part is presented on different forums such as conferences and meetings. Furthermore, among that, a large number of the studies are conducted in the two developed economies of the world, the United States of America and the United Kingdom. While experimental studies (i.e., the studies that have been classified on the sampling and collection tools of primary data, and statistical tools or software are applied to find the solution of the problem) are more in comparison to the secondary research studies.

Khatoon et.al.(2020), the resercher conducted an emprical study and applied the correlation and regression statitical tools to analysis the data collected from the 235 repondents of the different banks of Qatar through the closed ended questionnaire. The 


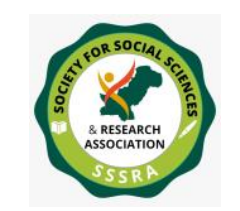

Pak. Journal of Int'L Affairs, Vol 4, Issue 2 (2021) Evaluation of Customer Relation Management ...

resutl of the estimation indicates E-banking quality service including the trustworthiness, competence, feedback, interaction, safety, security and privacy have positive and significant effect on the customer satisfaction to build long term assciation with an institution and willingness to purchase product.

Alokla, et al. (2019), according to the CRM is not a new idea, however it's far based totally at the present day improvement in business enterprise software technology. Also, corporations use this idea to win the agree with and the loyalty in their clients. This allows facilitate profitability in business. To achieve this, the CRM machine desires to hyperlink back and front office packages.

$\underline{\operatorname{Rai}(2013)}$, states that customer relationship management is a model for to keep the strong relationship with the existing and future customers. Initially the information technology business during the mid of the 20th century started to practice on this model. Since Then, CRM has been adapted in the industrial sector and service sector to maintain interaction with the existing and future customers in a competitive market for a long period. Furthermore, the CRM has been proved to be a profitable business model in comparison to the traditional marketing sources for a longer period.

Payne \& Frow (2013) the significance of the CRM is extensively acknowledged a lot in service sector however the main factor is the expanding contribution of data innovation in customer relationship management. Moreover, the authors characterizing the center capacity of the banks are of customer services and the principle area of a bank that can offer quality types of assistance and these ought to be according to the expectation of a client that the client consistently anticipates that the bank should satisfy his necessities.

Jahanzaib, et.al, (2015), for a comparative experimental study the 200 respondents were selected from the public and private banks branches of Lahore city of Pakistan. The finding of the test shows that the individual having account in the private banks were more satisfied from the service of the private banks in compare to the public banks due to the use of the latest technology, digital touch, branch location, customer services and etc.

Mishra, et.al; (2011), the empirical study shows that the first-hand information is collected through a questionnaire based survey from the 337 bank customers of public and private banks branches of Orissa India. The $X^{2}$ and t-test have been adopted to 


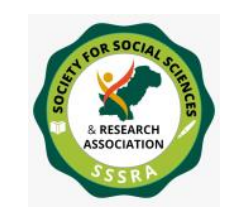

Pak. Journal of Int'L Affairs, Vol 4, Issue 2 (2021) Evaluation of Customer Relation Management ...

understand the applications of CRM in the public and private banks. The study found out that both private and public sector banks in India is facing major issues to retain the current customer and attract new customers. The main hurdle in this respect is to develop a long-term business relationship with the customer, which is lack of practice on the concept of CRM.

Chaudhary (2011) is of the opinion that the contribution of the financial institutions particularly banks in social and economic development of country is remarkable. With the establishment of private banks, the circumstance of the service sector changed proficient administration, and innovation has expanded the exhibition of the financial business by offering quality types of customer services to the clients.

Ganesamathury et.al. (2011) the researcher have noticed that the financial institutions, especially the banks and financial institutions sector have perceived the idea of customer relationship management to fabricate solid associations with current clients and fortify the trust of clients working with the business institutions, by discovering an answer for the monetary feature, enter new client to the business overlap by rousing them to buy results of the bank and in this way help to keep up the benefits of the matter of a bank.

Pokharel, (2011), is of openion that the customer relationship management is the methodology that ought to be empowered the organization in the perfect competition market by retaining your customer. The banks should facilitate to customers to grow their business profitable by reduction in the interest rate and discount in the schedule charges of the bank. The priority of banks (public and private) is to incorporate the customer relation management in a priority to edge over the competitors. The most important aim of the CRM is to build long-term relationship with the existing and by understanding their needs to attract future customers.

Reiman, et.al; (2010) according to the researchers the holding of the bank and the exercises of client relationship the board capacities are indistinguishable in light of the fact that it isn't practical for the bank to do beneficial business of this cutting edge.

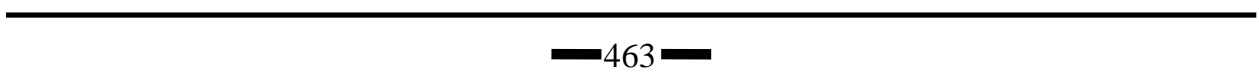




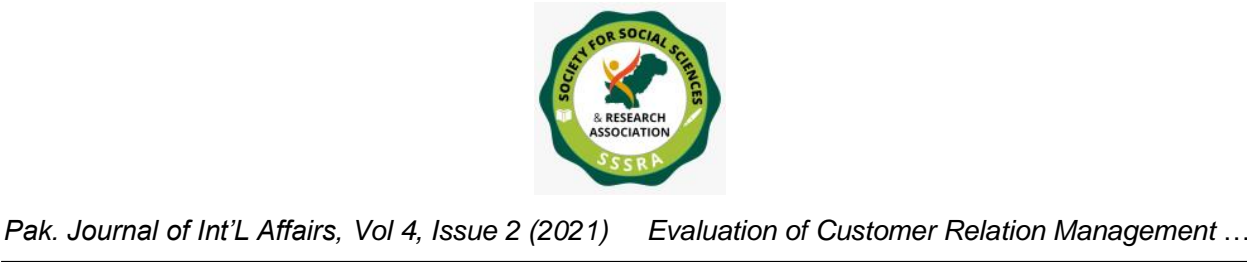

Levesque (2009), the researcher characterizes customer relationship management as an action cycle around the client beginning with the clients' necessities. According to the author firms frequently make the decline in their current client base, if the new item isn't as indicated by the expectations of the buyer, particularly the current customer as this will turn into the reason for a distinction of assessment between the current client and the firm and the firm regularly loses the client. To keep away from loss of a profitable client and to create with them long haul relationship, at that point it is vital for know the assumptions for the customer and the buyer have for the product and the quality of customer service.

Jasola (2008) has the assessment that in this time of rivalry, the client of the financial area of India needs to look over the items and administrations which are credited to the result of a firm. So the believability of agents and limited time action relies on the assistance of the bank in giving the assumptions for the client is in the business overlay. The excellent customer services inspires the client to impart his experience to the others and that assists with getting another useful section, and comparably increment the worth of the confidence of the workers and clients of the bank.

Christopher, et.al; (2008) the idea of CRM states the fundamental significance of embracing the various methodologies of promoting to hold the client when before and after the sale of a product to the client. These days, the individual relationship with the client is centered around the uses of data innovation those aides in keeping up long-haul connections. On the off chance that upon the augmentation of the quality assistance and association's prosperity to the client not to move towards its rival, but rather for a similar steadfast client to work for the development of the bank or firm as its agent.

$\underline{\operatorname{Lau}}$ (2003), it isn't adequate for the bank to have refreshed data of customers, however it is an incredible test for them to choose the best an ideal opportunity to utilize that data to dispatch another applicable item to sell them.

Humby \& Hunt, (2003), Stressed that with more spending on the area of the customer relationship management section of the firm, will be advanced the firm to give better products according to their expectation to their clients and to fulfill their needs by which they can hold the beneficial client and bring new clients into their business fold.

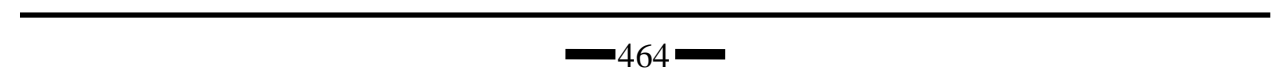




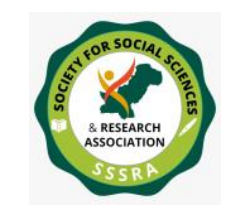

Pak. Journal of Int'L Affairs, Vol 4, Issue 2 (2021) Evaluation of Customer Relation Management ...

\section{Study Design and Methodology}

> The questionnaire-based survey conducted to get the primary data from the 249 respondents. The sample size has been selected from the absolute 700 existing clients of both Public and Private Banks branches of Jamshoro with the assistance of the measurable equation. The sample was selected on the accompanying rules.

$>$ The clients having a business relationship with the chose throughout the previous five years

$>$ The selected clients are getting and have benefited themselves of the credit from the bank.

$>$ The selected clients are occupied with some business like import or export.

Table no. 1, Breakup of Sample Size

\begin{tabular}{|c|c|c|c|}
\hline Banks & Saver/Investor & $\begin{array}{c}\text { Availed credit } \\
\text { Facility }\end{array}$ & Total \\
\hline Public & 23 & 91 & 114 \\
\hline Private & 11 & 124 & 135 \\
\cline { 2 - 3 } & \multicolumn{2}{|r}{} \\
\cline { 3 - 4 }
\end{tabular}

The mean, standard deviation, T-test, and CHI square measurement tools have been applied to find the variance between the public and private banks with reference to the practices of the Customer Relationship Management.

\section{Objective:}

$>$ To evaluate the impact of Customer relationship Management practices offered by the public and private banks and the quality customer services facilities.

$>$ To ascertain the variance between the quality services and customer relationship management in the public and private banks

\section{Hypotheses:}

H1: There is a significant difference between public and private banks with reference to customer services 
H0: There is no significant difference between public and private banks with reference to customer services.

H2: There is a significant difference in the attitude and aptitude of staff of the public and private banks with their customers.

H0: There is no significant difference in the attitude and aptitude of staff of the public and private banks with their customers.

\section{Result and Discussion:}

The main point of this investigation was to find the variance about CRM practices in public and private banks of Pakistan. The essential information gathered through the organized questionnaire based survey. Perspectives on the respondents have been measured with the help of the five-point Likert scale. The questionnaire includes the quality of customer service, schedule bank charges, use of information technology, and frequency of usage of the bank, customer satisfaction and aptitude and attitude of the bank staff. Such demographic position has been collected along with qualitative data. The same can be envisaged from table no.2, attached underneath: 
Pak. Journal of Int'L Affairs, Vol 4, Issue 2 (2021) Evaluation of Customer Relation Management ...

Table no. 2, Customer Profile by Type of Banks

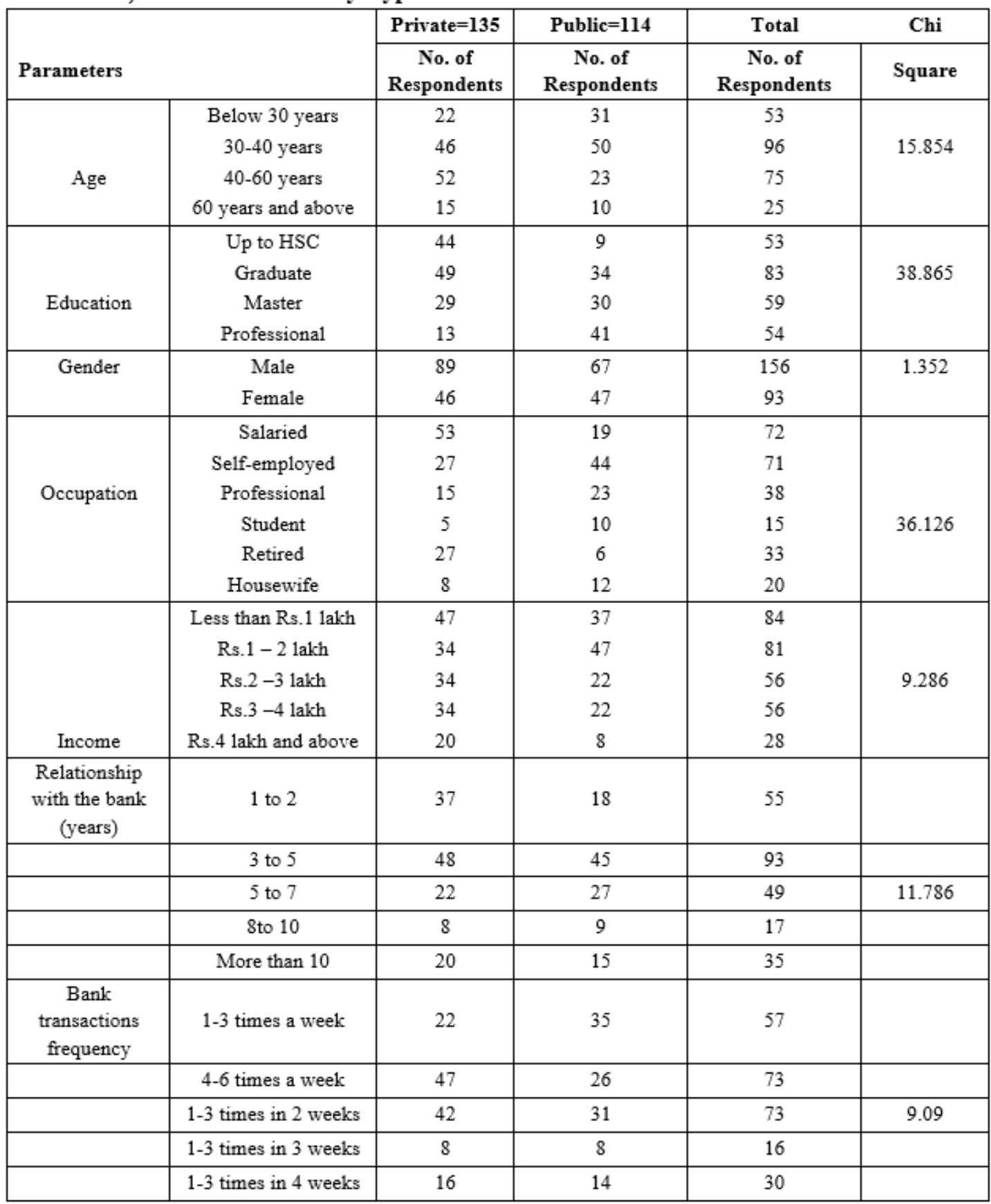


Pak. Journal of Int'L Affairs, Vol 4, Issue 2 (2021) Evaluation of Customer Relation Management ...

Table no.3, Purpose of Account opening tested through CHI Square application N=249

\begin{tabular}{|c|c|c|c|c|}
\hline & \multicolumn{2}{|c|}{$\begin{array}{l}\text { Private Banks } \\
\qquad \mathrm{N}=135\end{array}$} & \multicolumn{2}{|c|}{$\begin{array}{c}\text { Public Banks } \\
\qquad \mathrm{N}=114\end{array}$} \\
\hline & $\begin{array}{l}\text { Expected } \\
\text { value }\end{array}$ & $\begin{array}{l}\mathrm{X}^{2} \\
\text { value }\end{array}$ & $\begin{array}{l}\text { Expected } \\
\text { value }\end{array}$ & $\begin{array}{l}\mathrm{X}^{2} \\
\text { value }\end{array}$ \\
\hline Close to home /office & 26.02 & 0.95 & 21.98 & 1.13 \\
\hline Alluring Financial Products & 26.57 & 3.44 & 22.43 & 4.08 \\
\hline Salary Accounts & 30.90 & 5.55 & 26.10 & 6.57 \\
\hline Accessibility of ATMs & 20.60 & 0.63 & 17.40 & 0.75 \\
\hline Suggested by Friends & 16.81 & 3.63 & 14.19 & 4.29 \\
\hline Others & 14.10 & 0.60 & 11.90 & 0.71 \\
\hline
\end{tabular}

$1 \%$ significant value

The X2 value demonstrates the alluring monetary Products, and suggested by the companions and accessibility of the ATM are the primary purposes behind the record opening in the private banks. It is genuinely important to enter new clients in the business circle of the private bank.

\section{Customer Services and Technical Assistance}

Figure no.1, Customers' Satisfaction with Ability to Resolve Complaints n=249

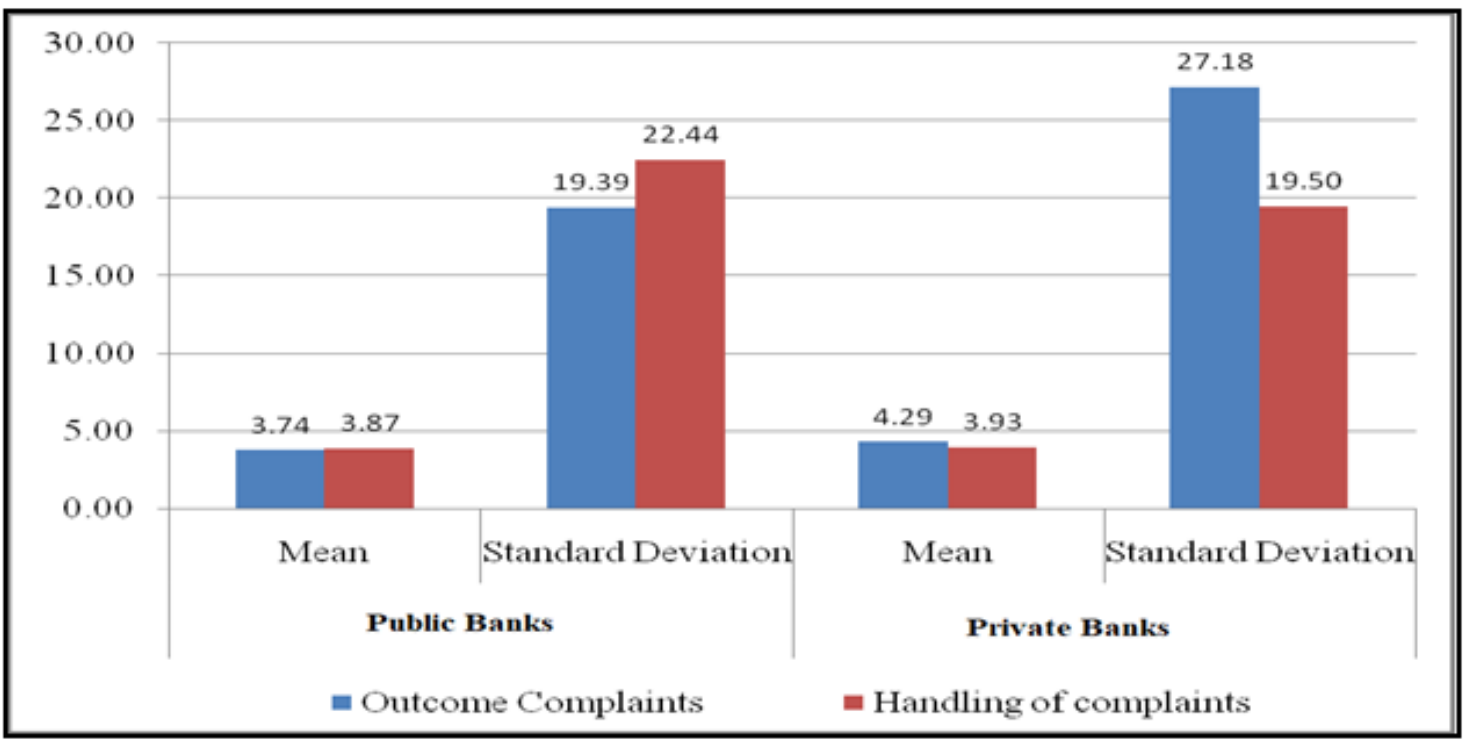

Source. Field Survey, 2019 


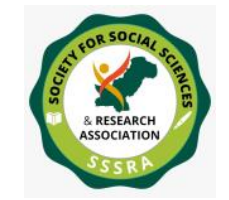

Pak. Journal of Int'L Affairs, Vol 4, Issue 2 (2021) Evaluation of Customer Relation Management ...

Figure 1, shows the capacity of the bank staff to determine client inquiries at the level of their fulfillment. The mean value 4.29 and 3.93 of the result of the customer's queries and customer satisfaction of level of private banks against the mean values 3.74 and 3.87 of a public bank. The consistency of the answer to the complaint of the customer can look from the standard deviation of a private and public bank.

\section{Figure no.2, Technical Assistance by the Banker to the Customer}

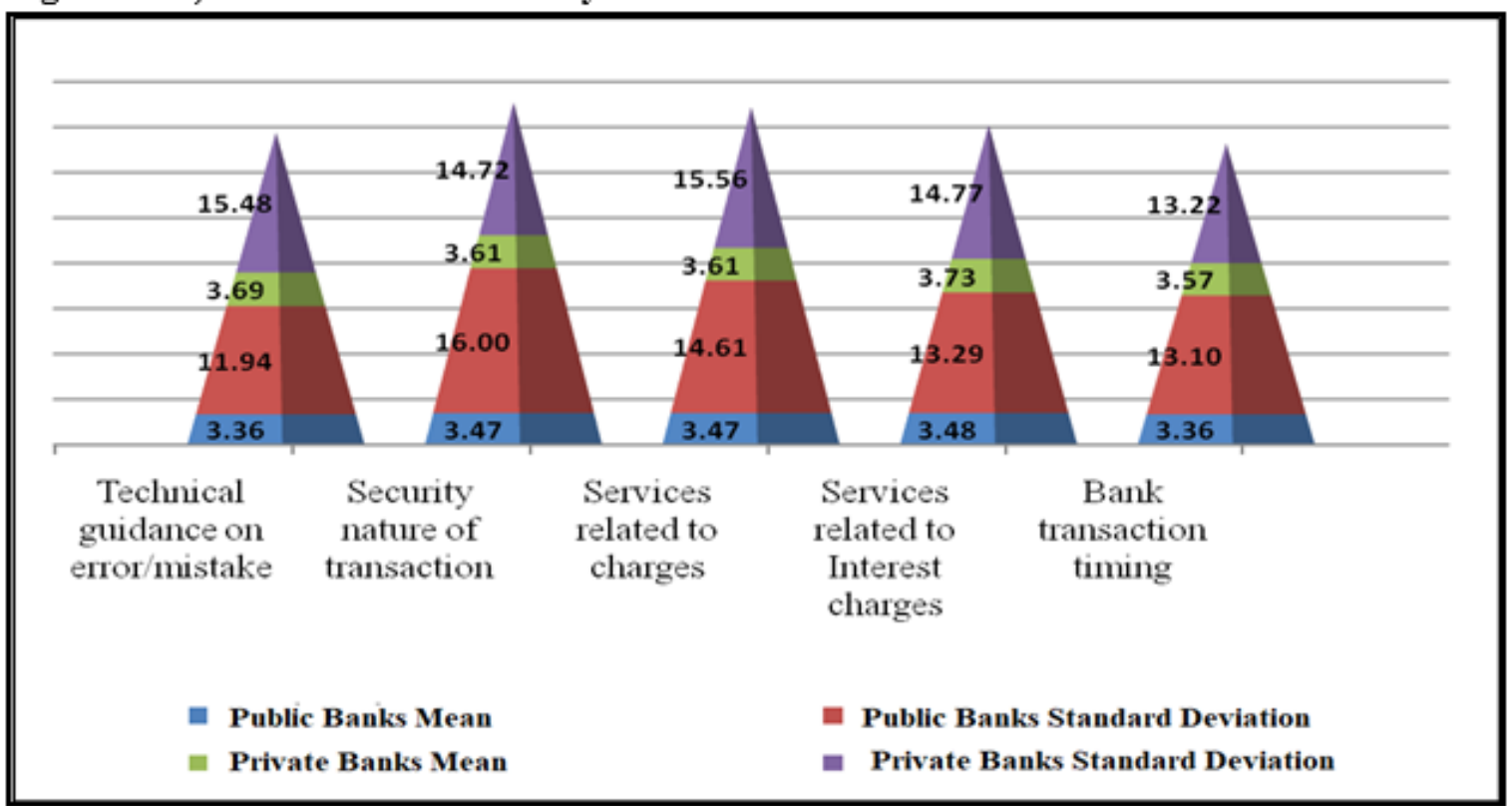

Figure no.2, shows the perspectives on the respondents about technical problems are resolve by the bank. The mean 3.69 shows that the specialized services are provided by the private banks to resolve the technical difficulties to complete transaction is higher against the 3.36 mean of the respondents of the public bank while 3.73 mean value the private bank offers better types of assistance to comprehend the computation of interest amount in comparison to public bank 3.48 mean value. The means value 3.57 indicates that private bank takes little time to complete/settle. While the public bank sets aside less effort to settle the transaction can be judged from mean value 3.36.

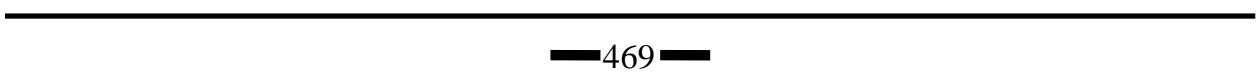


Pak. Journal of Int'L Affairs, Vol 4, Issue 2 (2021) Evaluation of Customer Relation Management ...

\section{Discussion and Analysis:}

$\exists$ Table no.4, Result of Independent Samples Test- Customer Services

\begin{tabular}{|c|c|c|c|c|c|c|c|}
\hline \multirow[t]{3}{*}{ Variables } & \multicolumn{3}{|c|}{ Lexene's Test for Equality of Variances } & \multicolumn{4}{|c|}{ t-test for Equality of Means } \\
\hline & & \multirow[b]{2}{*}{$\mathrm{F}$} & \multirow[b]{2}{*}{ Sig. } & \multirow[b]{2}{*}{$\mathrm{t}$} & \multirow[b]{2}{*}{ df } & \multirow{2}{*}{$\begin{array}{c}\text { Sig. } \\
(2- \\
\text { tailed) }\end{array}$} & \multirow{2}{*}{$\begin{array}{c}\text { Mean } \\
\text { Difference }\end{array}$} \\
\hline & & & & & & & \\
\hline \multirow{2}{*}{$\begin{array}{c}\text { Network, } \\
\text { Spread \& No. } \\
\text { of ATMs }\end{array}$} & Equal variances assumed & 2.70 & 0.10 & 3.47 & 247.00 & 0.00 & 4.06 \\
\hline & Equal variances not assumed & & & 3.48 & 242.03 & 0.00 & 4.06 \\
\hline \multirow{2}{*}{$\begin{array}{l}\text { Service } \\
\text { Enabled } \\
\text { through } \\
\text { ATMs }\end{array}$} & Equal variances assumed & 0.20 & 0.65 & 5.19 & 247.00 & 0.00 & 6.34 \\
\hline & Equal variances not assumed & & & 5.23 & 245.53 & 0.00 & 6.34 \\
\hline \multirow{2}{*}{$\begin{array}{c}\text { Location of } \\
\text { ATMs Safety } \\
\text { and Security } \\
\text { Easy Access } \\
\text { to ATMs }\end{array}$} & Equal variances assumed & 4.17 & 0.04 & 2.51 & 247.00 & 0.01 & 3.39 \\
\hline & Equal variances not assumed & & & 2.55 & 246.90 & 0.01 & 3.39 \\
\hline \multirow{2}{*}{$\begin{array}{c}\text { Cheque Drop } \\
\text { Boxes }\end{array}$} & Equal variances assumed & 26.80 & 0.00 & 2.69 & 247.00 & 0.01 & 3.28 \\
\hline & Equal variances not assumed & & & 2.72 & 246.98 & 0.01 & 3.28 \\
\hline \multirow{2}{*}{$\begin{array}{l}\text { Prompt Issue } \\
\text { of Credit / } \\
\text { ATM Cards }\end{array}$} & Equal variances assumed & 72.50 & 0.00 & 1.18 & 247.00 & 0.24 & 1.20 \\
\hline & Equal variances not assumed & & & 1.14 & 185.09 & 0.26 & 1.20 \\
\hline \multirow{2}{*}{$\begin{array}{c}\text { Accuracy of } \\
\text { Monthly } \\
\text { Statements }\end{array}$} & Equal variances assumed & 16.07 & 0.00 & -0.87 & 268.00 & 0.38 & -1.36 \\
\hline & Equal variances not assumed & & & -0.87 & 250.44 & 0.38 & -1.36 \\
\hline \multirow{2}{*}{$\begin{array}{c}\text { Timely } \\
\text { Renewal of } \\
\text { Credit Card }\end{array}$} & Equal variances assumed & 3.85 & 0.05 & 4.28 & 247.00 & 0.00 & 7.29 \\
\hline & Equal variances not assumed & & & 4.23 & 225.51 & 0.00 & 7.29 \\
\hline \multirow{2}{*}{$\begin{array}{c}\text { Receipt of } \\
\text { Monthly } \\
\text { Statement in } \\
\text { Time }\end{array}$} & Equal variances assumed & 2.39 & 0.12 & 1.99 & 247.00 & 0.05 & 2.59 \\
\hline & Equal variances not assumed & & & 1.98 & 233.27 & 0.05 & 2.59 \\
\hline \multirow{2}{*}{$\begin{array}{c}\text { Transparency } \\
\text { in Service } \\
\text { Charges }\end{array}$} & Equal variances assumed & 26.09 & 0.00 & 5.09 & 247.00 & 0.00 & 6.72 \\
\hline & Equal variances not assumed & & & 5.22 & 241.83 & 0.00 & 6.72 \\
\hline \multirow{2}{*}{$\begin{array}{c}\text { Wide } \\
\text { Acceptability } \\
\text { of Card }\end{array}$} & Equal variances assumed & 11.29 & 0.00 & 3.97 & 247.00 & 0.00 & 5.04 \\
\hline & Equal variances not assumed & & & 3.95 & 234.62 & 0.00 & 5.04 \\
\hline \multirow{2}{*}{$\begin{array}{c}\text { Proper } \\
\text { Service on } \\
\text { Phone } \\
\text { Banking }\end{array}$} & Equal variances assumed & 2.93 & 0.09 & 7.78 & 247.00 & 0.00 & 9.38 \\
\hline & Equal variances not assumed & & & 8.00 & 240.20 & 0.00 & 9.38 \\
\hline
\end{tabular}


Table no.4, The t-test for equality of variance and means of the variables involved in customer services shows that $\mathrm{P}=<0.05$, except the variables ATM, Credit cards and Account Statements while their mean values show the difference between customer services of public and private banks. Therefore, we accept the alternative hypotheses "There is a significant difference between public and private banks with reference to customer services" and reject the null hypotheses.

\section{Aptitude and Attitude of Bank Staff}

Table no.5, Result of Independent Samples Test-Aptitude and attitude of Bank Staff

\begin{tabular}{|c|c|c|c|c|c|c|c|}
\hline \multicolumn{2}{|l|}{ Variables } & \multicolumn{2}{|c|}{$\begin{array}{l}\text { Leyene's. Test } \\
\text { for Equality of } \\
\text { Variances }\end{array}$} & \multicolumn{4}{|c|}{ t-test for Equality of Means } \\
\hline & & $\mathrm{F}$ & Sig. & $\mathrm{T}$ & Df & $\begin{array}{l}\text { Sig. (2- } \\
\text { tailed) }\end{array}$ & $\begin{array}{c}\text { Mean } \\
\text { Difference }\end{array}$ \\
\hline $\begin{array}{c}\text { Courtesy of } \\
\text { the banks" } \\
\text { staff }\end{array}$ & $\begin{array}{l}\text { Equal } \\
\text { variances } \\
\text { assumed } \\
\text { Equal } \\
\text { variances not } \\
\text { assumed }\end{array}$ & 65.73 & 0.00 & $\begin{array}{l}-5.42 \\
-5.62\end{array}$ & $\begin{array}{l}247.00 \\
231.22\end{array}$ & $\begin{array}{l}0.00 \\
0.00\end{array}$ & $\begin{array}{l}-9.91 \\
-9.91\end{array}$ \\
\hline $\begin{array}{l}\text { Helpfulness of } \\
\text { the bank staff }\end{array}$ & $\begin{array}{l}\text { Equal } \\
\text { variances } \\
\text { assumed } \\
\text { Equal } \\
\text { variances not } \\
\text { assumed }\end{array}$ & 31.26 & 0.00 & $\begin{array}{l}-6.12 \\
-6.17\end{array}$ & $\begin{array}{l}245.00 \\
244.77\end{array}$ & $\begin{array}{l}0.00 \\
0.00\end{array}$ & $\begin{array}{l}-11.39 \\
-11.39\end{array}$ \\
\hline $\begin{array}{c}\text { Knowledge of } \\
\text { the banks" } \\
\text { staff }\end{array}$ & $\begin{array}{l}\text { Equal } \\
\text { variances } \\
\text { assumed } \\
\text { Equal } \\
\text { variances not } \\
\text { assumed } \\
\end{array}$ & 6.21 & 0.01 & $\begin{array}{l}-3.08 \\
-3.03\end{array}$ & $\begin{array}{l}247.00 \\
218.87\end{array}$ & $\begin{array}{l}0.00 \\
0.00\end{array}$ & $\begin{array}{l}-6.39 \\
-6.39\end{array}$ \\
\hline $\begin{array}{c}\text { Bank } \\
\text { information } \\
\text { delivery to the } \\
\text { customer }\end{array}$ & $\begin{array}{l}\text { Equal } \\
\text { variances } \\
\text { assumed } \\
\text { Equal } \\
\text { variances not } \\
\text { assumed }\end{array}$ & 86.42 & 0.00 & $\begin{array}{l}-9.27 \\
-9.57\end{array}$ & $\begin{array}{l}247.00 \\
236.47\end{array}$ & $\begin{array}{l}0.00 \\
0.00\end{array}$ & $\begin{array}{l}-14.65 \\
-14.65\end{array}$ \\
\hline $\begin{array}{l}\text { Quality of } \\
\text { information } \\
\text { received }\end{array}$ & $\begin{array}{l}\text { Equal } \\
\text { variances } \\
\text { assumed } \\
\text { Equal } \\
\text { variances not } \\
\text { assumed }\end{array}$ & 4.09 & 0.04 & $\begin{array}{l}-5.38 \\
-5.23\end{array}$ & $\begin{array}{l}247.00 \\
199.55\end{array}$ & $\begin{array}{l}0.00 \\
0.00\end{array}$ & $\begin{array}{l}-10.25 \\
-10.25\end{array}$ \\
\hline $\begin{array}{c}\text { The attitude of } \\
\text { the banks" } \\
\text { staff }\end{array}$ & $\begin{array}{l}\text { Equal } \\
\text { variances } \\
\text { assumed } \\
\text { Equal } \\
\text { variances not } \\
\text { assumed }\end{array}$ & 18.37 & 0.00 & $\begin{array}{l}-6.32 \\
-6.42\end{array}$ & $\begin{array}{l}247.00 \\
246.93\end{array}$ & $\begin{array}{l}0.00 \\
0.00\end{array}$ & $\begin{array}{l}-12.55 \\
-12.55\end{array}$ \\
\hline
\end{tabular}




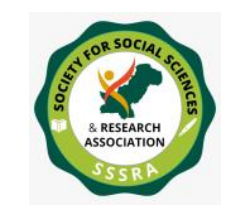

Pak. Journal of Int'L Affairs, Vol 4, Issue 2 (2021) Evaluation of Customer Relation Management ...

Table no. 5 shows the $\mathrm{p}=<0.05$, the result indicates respondents experience concerning courtesy and helpfulness of the bank staff, job knowledge, and information delivery to the customer.

The outcome demonstrates staff experience concerning knowledge, management and creativity of the bank staff, job knowledge, and interaction with the customer to resolve the queries in proper time and data conveyance to the client. The $p$ value is less than 0.05 shows there is significant difference between the attitude and aptitude of employees of public and private banks in CRM practices. Therefore, we accept the alternative hypotheses " There is a significant difference in the attitude and aptitude of staff of the public and private banks with their customers" and reject the null hypotheses. Furthermore, the same can also be envisaged from figure no. 02, that how the employees of public and private banks provide technical assistance the customers in the mutual benefit of the both (i.e Bank and customer). The combined mean value 4.30 and standard deviation 26.75 of technical assistance provided by the private banks worker to customer is greater than public banks employee mean and standard deviation value 3.68 and 18.46. It is sufficient evidence that shows variance that in practice on the concept of customer relationship for customer satisfaction.

\section{Figure no. 03, Customer Satisfaction regarding receptiveness of the Bank Staff}
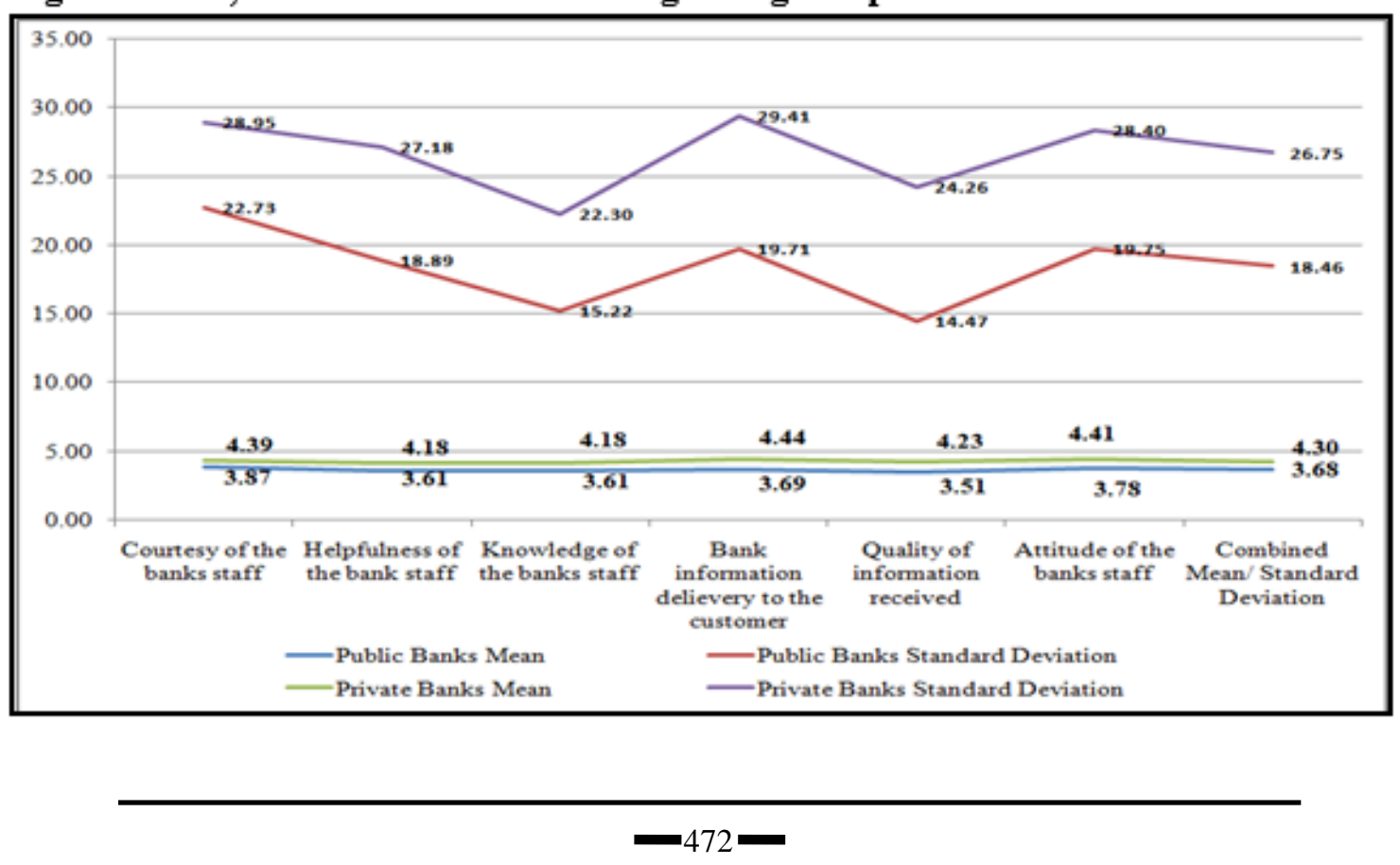


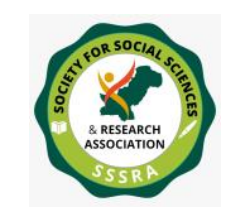

Pak. Journal of Int'L Affairs, Vol 4, Issue 2 (2021) Evaluation of Customer Relation Management ...

\section{Conclusion}

The analysis of the data shows of primary data highlights variance between the variables of the customer relationship management of public and private banks. Therefore, the management of the local bank should have to improve them in case of CRM practices and to increase the knowledge, creativity, and management of the employees.

The most important aspect of the foreign banks CRM practices is the continuous development of the employees in the areas of knowledge, creativity, management, and use of modern technology.

\section{LIMITATION AND STUDY FORWARD}

The current study professed that the customer relationship management is used to build a sound relationship for the mutual benefit of both, i.e., the institution and the customer. Therefore, the study will contribute more in the knowledge, management and creativity in the banking sector. The study will also provide more for the future researchers to examine the knowledge, management and creativity of the workforce of the service sector.

\section{Recommendations:}

- Public banks consistently adopt the CRM practices with digital touch and to retain the profitable customer, to build a long-term relationship with the customer, to understand the needs of the customer, and to satisfy the customer.

- The management of the local bank should have to improve them in case of CRM practices and to increase the knowledge, creativity, and management of the employees.

- So it is important to pay attention to the customer by catering to the needs of the customer and to build his trust and confidence with the organization. Otherwise, to retain a profitable customer by force or by the features of a product is not possible because the product-centric approach is outdated.

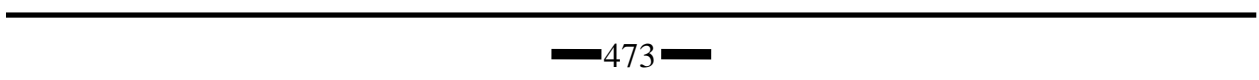


Pak. Journal of Int'L Affairs, Vol 4, Issue 2 (2021) Evaluation of Customer Relation Management ...

Dr. Imdad Ali Khowaja: Data Analysis and its interpretation, Abstract and Conclusion writing.

Kamleshwer Lohana: Data Collection, working on literature, writing references and after completion of research review the article.

Anil Bhatia: Data Collection, working on literature, writing references and after completion of research review the article

\section{References:}

Alokla, M., Alkhateeb, M., Abbad, M., \& Jaber, F. (2019). Customer Relationship Mangement: A Review and Classification. Transational Marketing Journal , 7 (2), 187-210.

Anderson, J. C., Narus, J. A., \& Van, R. W. (2006). Customer Value propositionms in Business Markets. 84 (3).

Bagram, M. M. (2010). CRM in the Banking Sector of Pakistan. A Ph.D Thesis, NUML Islamabad .

Blaxter, L., Hughes, C., \& Tight, M. (2000). How to Reserch. New Delhi: VIVA Books Pvt. Ltd.

Brink, A., \& Berndt, A. (2008). Relationship Marketing and Customer Relationship Management. South Africa: JUTA and Co. South Africa.

Caroline, M., \& Elizabeth, M. (2014). Determinants of Customer Retention in Commercial Banking in Tanzania. Journal of Finance and Risk Managment, 2 (1).

Chaudhary, K. a. (2011). Performance of Indian public sector banks and private sector banks: A comparative study. International journal of innovation, management and technology, 2 (3).

$-474=$ 
Pak. Journal of Int'L Affairs, Vol 4, Issue 2 (2021) Evaluation of Customer Relation Management ...

Chotani, P. S., \& Naraynan, L. (2010). CRM in Banking Industry. Executive MBA Jobs, .

Christopher, M., Payne, A., \& Ballantyne, D. (2008). Relationship Marketing: Creating Stakeholder Value.

Ganesamathury, K., Amilan, S., \& Jothi, M. (2011). The Customer's Attitude on CRM Practices of Commercial Banks in India: An empirical Study. 6 (1).

Frederick, F. R., \& W., E. S. (October, 2009). Zero Defections:Quality Comes to Services, . Harward Business Review .

Furness, P. (2001). Techniques of Customer Modelling in CRM. Journal of Financial Services Marketing, 5 (4).

Ganesamathury, K., Amilan, S., \& Jothi, M. (2011). The Customer's Attitude on CRM Practices of Commercial Banks in India: An empirical Study. 6 (1).

Gronroos, C. (2000). Service Management and Marketing: A Customer Relationship Management Approach (2nd ed.). John Willey \& Sons Ltd.West Sussex.

Haq, W. U., \& Muhammad, B. (2012). Customer Satisfaction: A comparison of Public and Private Banks of Pakistan. Journal of Business and Management (IOSRJBM), 1 (5), pp 04-09.

Hawks, V. A. (2000). The heart of the matter: the challenges of customer lifetine value. CRM, Forum Resources, London.

Humby, C., \& Hunt, T. (2003). Scoring Points: How Tesco is winning customer Loyalty. Kogan Page, London. 
Pak. Journal of Int'L Affairs, Vol 4, Issue 2 (2021) Evaluation of Customer Relation Management ...

Jahanzaib, Aslam, A., \& Ahmad, K. (2015). Customer Satisfaction in Public and Private Banks of Pakistan: An Empirical Evidence from Lahore City. Bulletin of Business and Economics , 4 (4), 238-246.

Jasola, M. a. (2008). CRM: A Competitive tool for Indian banking sector.

Communications of the IBIMA, New Delhi, India.

John, W. C. (2013). Research Design: Qualitative, Quantitative, and Mixed Methods Approaches. SAGE Publication, USA.

Judith, W. K. (2011). Customer Relationship Management (5 ed.). Repo India Limited.

Khatoon, S., Zhengliang, X., \& Hussain, H. (2020). The Mediating Effect of Customer Satisfaction on the Relationship Between Electronic Banking Service Quality and Customer Purchase Intention: Evidence From the Qatar Banking Sector. SAGE Open , 10 (2), 1-12.

Kumar, R. (2011). Research Methodology: A step by Step Guide for Beginners (3rd ed.). SAGE Publication Limited, New Delhi, India.

Kumar, V., \& Reinartz, W. (2012). Customer Relationship Management. Spring, Heildelberg, New York, USA.

Lau K, W. S. (2003). Next product to offer for Bank Marketers. Journal of Database Marketing, 10 (4).

Levesque, T. a. (2009). Determination of Customers' Satisfaction in Retail Banking. International Journal of Marketing, 14 (7), 12-20.

Lewis, M. (2006). Customer Acquisation promotions and customer assets value,. 2 (43).

Lobel, I., Sadler, E., \& Varshney, L. R. (2016). Customer Referral Incentives and Social Media. (Informs, Producer) Retrieved January 12, 2017, from http://pages.stern.nyu.edu/ ilobel/Referral_Incentives.pdf 


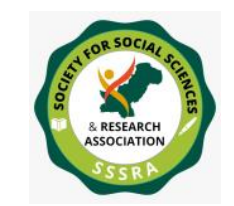

Pak. Journal of Int'L Affairs, Vol 4, Issue 2 (2021) Evaluation of Customer Relation Management ...

Mahmood, B., Abbas, M., \& Hussain, S. (2011). Customer Satisfaction with Service Quality in Conventional Banking in Pakistan: A Case Study Faisalabad. International Journal of Marketing Studies, 3 (4).

Merkle Inc. (2011). An Integrated Approach to Retail CRM. Merkle Thoght Leadership Series, 2 (3).

Meena, P., \& Sahu, P. (2021). Customer Relationship Management Research from 2000 to 2020: An Academic Literature Review and Classification. The Journal of Business Perspective , 25 (2), 136-158.

Mishra, U. S., Mishra, B. B., Praharaj, S., \& Mahapatra, R. (2011). CRM in Banks: A Comparative Study of Public and. European Journal of Social Sciences , 24 (2).

Ogarah, H., Pudaruth, S., Kumar, V., \& Anandkumar, V. (2011). A Study of Customer Perception of CRM Initiatives in the Indian Banking Sector. Research Journal of Social Science and Management, 1 (4).

Oliver, R. L. (2000). Satisfaction: A behavioral Perspective on Consumer. Mc Graw Hill, New York, USA.

Payne, A., \& Frow, P. (2013). Strategic Customer Management. Cambrige, University Press Newyork, USA.

Peter, C. V., \& Katherine, N. L. (February, 2013). Successful Customer Value Management: Key Lessons and Emerging Trends. Euorpean Management Journal, 1 (31).

Pokharel, B. (2011). Customer Relationship Management: Related Theories, Challenges and Application in Banking Sector. Banking Journal , 1 (1), 19-28.

Puthukulangara, M. D., \& Daniel, R. M. (2014, May). A COMPARATIVE STUDY ON THE CUSTOMER PERCEPTION OF THE CRM INITIATIVES OF PUBLIC

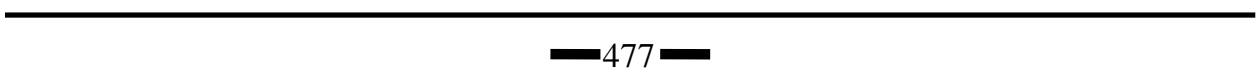


Pak. Journal of Int'L Affairs, Vol 4, Issue 2 (2021) Evaluation of Customer Relation Management ...

AND PRIVATE SECTOR BANKS IN THRISSUR DISTRICE, OF KERALA. International Journal of Research in Engineering and Technology, 03 (07).

Raab, G., Ajami, R. A., Garegya, V. B., \& Goddard, J. (2008). Customer Relationship Management: A Global Perspecive. New York, USA: Gower, New York, USA.

Rai, A. K. (2012). Customer Relationship Management Concept and Cases. PHI Learning Pvt. Limited, Delhi.

Rai, A. K. (2013). Customer Relationship Management Concepts and Cases. PHI LEARNING (PVT.) Limited, New Delhi, India.

Ravi, V. (2007). Advances in Banking Technology and Management: Impact of ICT and CRM. IGI Global, London United Kingdom.

Reiman, M., Schilke, O., \& Thomas, J. S. (2010). Customer relationship management and firm performance: the mediating role of business strategy. Journal of the Academy of Marketing Science, 38 (3).

Rust, R. T., Valarie, A. Z., \& Lemon, N. K. (2000). Driving Customer Equity: How customer lifetime value is Reshaping Corporate Strategy. New York: Free Press.

Sugandhi, R. K. (2003). Cutomer Relationship Management. New Age Publisher (P) Ltd., New Delhi, India. 